\title{
Kadar Aspal Optimum Laston Lapis Aus Menggunakan Abu Jerami Sebagai Pengganti Filler
}

\author{
Nikodemus Tandung*1, Rais Rachman*2, Alpius ${ }^{3}$ \\ *1 Mahasiswa Program Studi Teknik Sipil, Universitas Kristen Indonesia Paulus Makassar, \\ Indonesia nikotandung@gmail.com \\ *2,3 Dosen Program Studi Teknik Sipil, Universitas Kristen Indonesia Paulus Makassar, Indonesia ${ }^{2}$ \\ rais.rachman@gmail.com $*^{2}$ dan alpiusnini@gmail.com ${ }^{* 3}$
}

Corresponding Author: alpiusnini@gmail.com

\begin{abstract}
Abstrak
Aspal sebagai bahan pengikat dalam campuran LASTON pada sistem perkerasan lentur mempunyai pengaruh yang sangat penting terhadap umur rencana perkerasan. Oleh karena itu penggunaan kadar aspal menjadi hal yang sangat penting serta pemanfaatan limbah jerami sebagai bahan pengganti filler. Metode dalam penelitian ini adalah melakukan serangkaian percobaan sesuai dengan spesifikasi bina marga tahun 2018. Hasil penelitian menunjukan bahwa semua parameter karakteristik campuran yaitu stabilitas, flow, VIM, dan VFB memenuhi spesifikasi bina marga 2018 dan VMA pada kadar aspal 5,0\%-5,5\% tidak memenuhi spesifikasi dan VMA pada kadar aspal 6,0\%-7,0\% memenuhi spesifikasi. Dimana kadar aspal yang digunakan yaitu 5,0\%, 5,5\%,6,0\%,6,5\%, dan 7,0\%. Kadar aspal optimum yang didapatkan yaitu kadar aspal 7,0\%.
\end{abstract}

Kata kunci: Jerami, KAO, AC WC, Filler

\begin{abstract}
Asphalt as a binder in the LASTON mixture in flexible pavement system has very important influence on design life of the pavement. Therefore, the use of asphalt content is very important as well as the use of straw waste as filler substitute. The method this study is in accordance with the specifications the Bina Marga 2018. The results showed that all the characteristics of the mixture, stability, flow, VIM, and VFB meet the Bina marga 2018 specifications and VMA at asphalt levels of 5.0\% -5.5\% don't meet specifications and VMA at asphalt levels 6.0\% -7.0\% meets specifications. Where the asphalt content used is $5.0 \%, 5.5 \%, 6.0 \%, 6.5 \%$, and $7.0 \%$. The optimum asphalt content obtained is asphalt content $7.0 \%$.
\end{abstract}

Keywords: hay, KAO, AC WC, Filler

\section{PENDAHULUAN}

Salah satu lapisan dari perkerasan lentur adalah lapisan permukaan (Surface Course). Fungsi lapisan permukaan adalah sebagai bahan perkerasan untuk menahan beban roda, sebagai lapisan rapat air untuk melindungi badan jalan dari kerusakan akibat cuaca, dan sebagai lapisan aus (wearing course)[1]. Bahan untuk lapis permukaan umumnya adalah campuran bahan agregat, filler, dan aspal dengan persyaratan bahan yang memenuhi standar spesifikasi. Ada beberapa jenis campuran yang dapat digunakan sebagai lapis 
permukaan pada perkerasan lentur salah satunya yaitu LASTON. Lapisan aspal beton (LASTON) disebut juga AC (Asphaltic Concrete) adalah suatu lapisan permukaan yang terdiri dari campuran aspal keras dan agregat yang bergradasi menerus, dicampur,dihamparkan dan dipadatkan dalam keadaan panas pada suhu tertentu [2].

Aspal sebagai bahan pengikat dalam campuran LASTON pada sistem perkerasan lentur mempunyai pengaruh yang besar terhadap umur pelayanan lapisan perkerasan jalan. Oleh karena itu kadar aspal dalam suatu campuran aspal menjadi bagian yang sangat penting. Kadar aspal optimum pada campuran harus memenuhi persyaratan spesifikasi, seperti stabilitas, VIM, VMA, VFB, dan flow [3].

Daya tahannya (durability) berupa kemampuan aspal mempertahankan sifat aspal akibat pengaruh cuaca dan tergantung pada sifat campuran aspal dan agregat. Sedangkan sifat adhesi dan kohesi yaitu kemampuan aspal mempertahankan ikatan yang baik. Sifat kepekaan terhadap temperaturnya aspal adalah material termoplastik yang bersifat lunak/cair apabila temperaturnya bertambah [4]

Penggunaan sumber daya alam yang dapat diperbaharui pada saat ini sangat dianjurkan untuk mendukung kelestarian alam, maka muncul ide untuk memanfaatkan bahan limbah atau bahan sisa dari hasil aktivitas manusia sebagai bahan pengganti atau bahan tambah dalam perkerasan jalan [5] [6]. Salah satunya memanfaatkan abu jerami sebagai pengganti filler dalam campuran LASTON lapis aus [7]. Abu jerami padi merupakan limbah dari hasil pertanian yang mengandung unsur silica yang dapat dimanfaatkan untuk bahan pengganti semen dalam campuran beton. Unsur silica dalam semen sebesar $20 \%$ sedangkan unsur silica dalam abu jerami sebesar 65,92\%. Pada penelitian ini abu jerami sebagai bahan pengganti filler.

LASTON adalah lapis permukaan yang terdiri dari campuran aspal keras dengan agregat yang bergradasi menerus, dicampur, dihamparkan, dan dipadatkan pada suhu tertentu. LASTON bersifat kedap air, mempunyai nilai struktur, awet, kadar aspal berkisar 4-7\% terhadap berat campuran dan dapat digunakan pada lalu lintas ringan, sedang, hingga berat. Campuran ini mempunyai tingkat kekakuan yang tinggi [8].

Agregat dibutuhkan pada lapisan struktur perkerasan sebagai bahan utama pembuatan perkerasan jalan dan juga merupakan bahan yang paling dominan menghimpun kekuatan campuran untuk konstruksi jalan [9]. Dalam campuran aspal beton terdapat dua jenis agregat yaitu agregat kasar dan agregat halus. Agregat kasar berfungsi memberikan stabilitas campuran dari kondisi saling mengunci dari masing-masing agregat kasar dan dari tahan suatu aksi perpindahan. Dan agregat halus berfungsi sebagai pengunci dan juga mengurangi rongga udara agregat kasar [10]. Agregat alam yang sering digunakan untuk konstruksi perkerasan merupakan bahan baku yang tidak dapat diperbaharui dan dalam jangka panjang ketersediaanya akan habis. Oleh karena itu diharapkan untuk selalu berinovasi dalam penggunaan bahan material alam yang dapat diperbaharui.

Filler adalah bahan material penyusun aspal beton yang lolos saringan No. 200 (0,075 mm). Fungsi filler dalam campuran aspal beton adalah sebagai pengisi partikel antara agregat sehingga rongga udara menjadi lebih kecil sehingga menghasilkan perkerasan yang tahan gesek dan penguncian antara agregat yang baik. Hal tersebut akan meningkatkan stabilitas campuran yang baik [11]. Filler yang biasa disebut juga bahan pengisi dapat diperoleh dari hasl pemecahan batuan secara alami maupun buatan. Yang terdiri dari debu batu, kapur padam, dan semen Portland atau bahan non plastis lainnya. Bahan pengisi harus kering dan bebas dari bahan lain yang menggangu [12]. Pemilihan jenis material sebagai filler sangat penting karena filler merupakan bahan pengisi yang sifatnya halus dan dapat mengisi rongga atau pori yang mempunyai diameter lebih kecil atau kurang dari 0,002 $\mathrm{mm}$ [8]. 
Dalam penelitian ini digunakan agregat batu Sungai Tiakka yang telah diteliti sebelumnya dalam campuran LASTON lapis aus, dalam penelitian itu menyatakan bahwa agregat tersebut dapat digunakan dalam lapis LASTON lapis antara (AC-BC) [13].

Dalam penelitian ini menggunakan abu jerami sebagai bahan pengganti semen dalam campuran LASTON lapis aus, dan diharapkan dapat meningkatkan mutu campuran dan juga ramah lingkungan. Abu jerami berasal dari batang padi dan daun padi yang sudah tidak digunakan lagi kemudian ditumbuk halus dan dibakar. Abu jerami padi dapat dimanfaatkan untuk abu gosok, bahan ameliorasi tanah asam dan bahan campuran dalam pembuatan semen hidrolik serta dapat dimanfaatkan dalam campuran batako/mortal, beton, dan campuran batu bata press.

Penelitian tentang abu jerami dan menggunakan Batu Sungai Tiakka pada campuran AC-BC juga pernah dilakukan oleh Pakka, dkk (2021) dengan hasil menunjukkan bahwa stabilitas, flow, VIM, VMA, dan VFB pada kadar abu jerami 0\%, 25\%, 50\% memenuhi spesifikasi Bina marga 2018, sedangkan VMA pada kadar abu jerami 75\% tidak memenuhi spesifikasi Bina marga 2018, dan VMA, VFB pada kadar abu jerami 100\% juga tidak memenuhi spesifikasi Bina marga 2018 [14]. Penelitian lainnya tentang Abu Jerami antara lain Pemanfaatan Limbah Abu Sekam Padi (Rice Husk Ash) Sebagai Subtitusi Material Pengisi Campuran AC-WC Terhadap Karakteristik Marshall [15]. Pengaruh Penggantian Bahan Pengisi Semen Dengan Kombinasi Abu Bata Dan Abu Sekam Padi Pada Campuran Aspal AC-WC [16]. Analisis Pengaruh Pemanfaatan Abu Sekam Sebagai Filler Pada Campuran Aspal Beton [17].

Tujuan penelitian ini adalah untuk mengetahui Kadar Aspal Optimum pada campuran Laston Lapis Aus (AC-WC) yang menggunakan Abu Jerami sebagai bahan pengganti Filler. Standar Rujukan/Acuan yang digunakan Pemeriksaan Karakteristik Filler Abu Jerami mengacu pada standard rujukan ASTM C136:2012. Agregat yang digunakan dari Suangai Tiakka dan semua parameter karakteristik campuran mengacu pada Spesifikasi Bina Marga tahun 2018.

\section{METODOLOGI}

\section{Tahapan Penelitian}

Tahapan awal dalam persiapan bahan yaitu pengambilan sampel agregat yang berada di Sungai Tiakka dan pengambilan sampel abu jerami di lokasi yang telah ditentukan. Abu jerami dikeringkan dan dibakar di lokasi pengambilan lalu dibawa ke Laboratorium untuk disaring dan diuji berat jenisnya. Sementara agregat langsung dibawa ke Laboratorium, sebelum melakukan pembuatan sampel terlebih dahulu agregat dipecahpecahkan sesuai dengan ukuran gradasi.

Setelah semua bahan telah siap kemudian dilakukan pembuatan benda uji, lalu diuji menggunakan alat Marshall. Dari pengujian tersebut didapatkan data, data tersebut kemudian dianalisa, dari hasil analisa kemudian ditarik sebuah kesimpulan.

\section{Lokasi Pengambilan Agregat dan Abu Jerami}

Lokasi pengambilan agregat berada di Sungai Tiakka. Sungai ini berada di kecamatan Saluputti, kabupaten Tana Toraja. Sungai ini berjarak sekitar $22 \mathrm{~km}$ dari kota makale. Sedangkan Jerami padi diambil di lahan pertanian yang berada di kelurahan Ratte Kurra, kecamatan Kurra, Kabupaten Tana Toraja yang berjarak sekitar 27 km dari kota makale. Bentuk material dapat dilihat pada Gambar 1. 

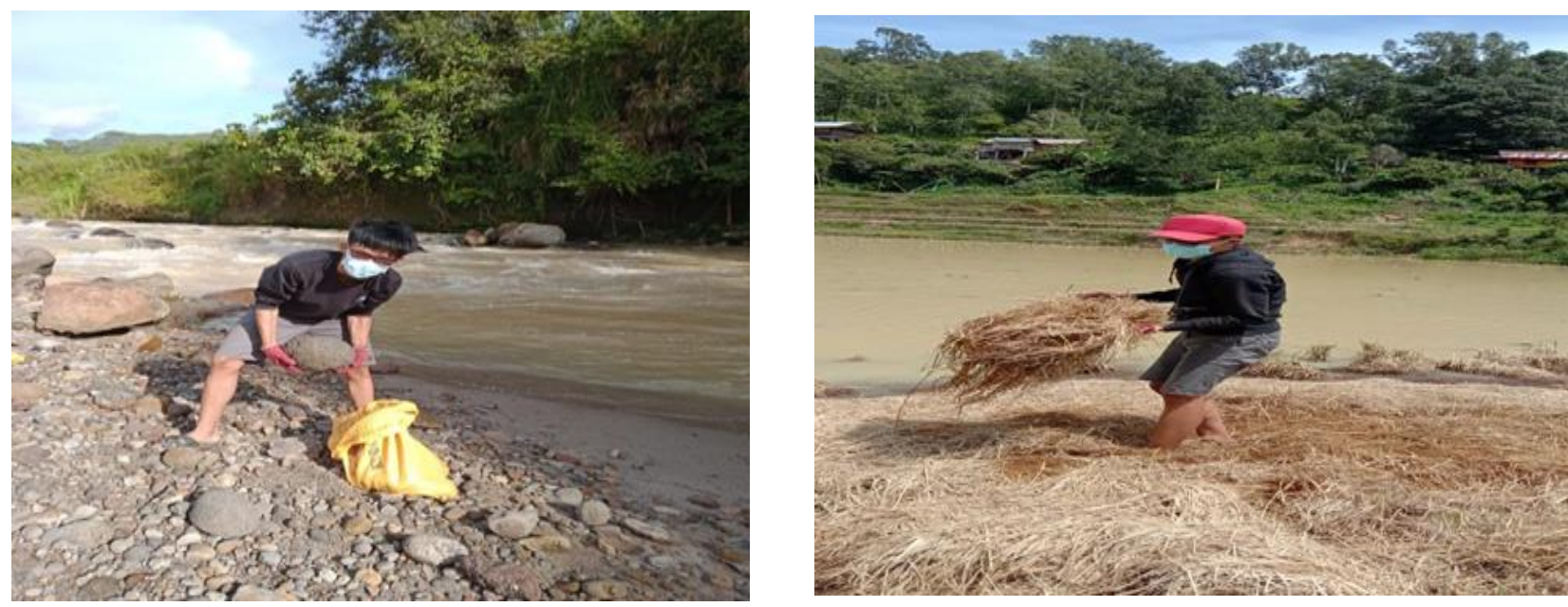

Gambar 1. Agregat dan Jerami

\section{Persiapan Material}

Persiapan material sebelum pemeriksaan dilakukan di Laboratorium yang mencakup pemecahan batu untuk mendapat kan ukuran-ukuran yang dibutuhkan sesuai dengan spesifikasi campuran LASTON lapis aus. Sedangkan untuk mendapatkan abu pada jerami padi maka terlebih dahulu jerami dikeringkan dengan cara dijemur langsung pada sinar matahari lalu dibakar Seperti pada Gambar 2.

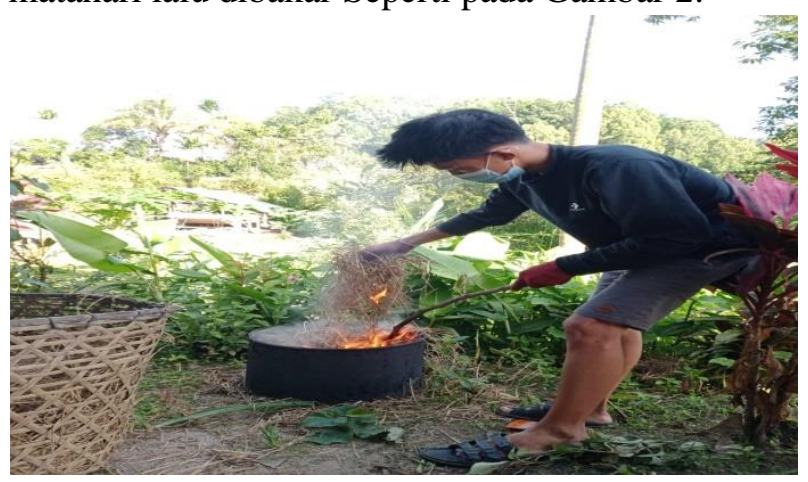

Gambar 2. Proses Pembakaran Jerami

\section{Karakteristik Filler Abu Jerami}

Pengujian ini dimaksudkan untuk mendapatkan berat jenis dari filler abu jerami yang lolos saringan No. 200 (0,075 mm). Standar rujukan pada pengujian ini yaitu SNI ASTM 136:2012.

\section{Pembuatan Benda Uji Untuk Campuran Laston Lapis Aus}

Pada pengujian karakteristik campuran LASTON lapis aus yang menggunakan abu jerami sebagai bahan pengganti filler dengan metode pengujian marshall test yang menggunakan variasi 5 variasi kadar aspal yaitu $5,0 \%, 5,5 \%, 6,0 \%, 6,5 \%$ dan 7,0\%. Maka diperlukan benda uji masing-masing kadar aspal menggunakan 3 benda uji. Jadi total benda uji yang digunakan yaitu 15 buah, seprti terlihat pada Tabel 1 . 
Tabel 1. Rancangan Jumlah Benda Uji Campuran

\begin{tabular}{cc}
\hline & Laston lapis aus \\
\cline { 2 - 2 } & Jumlah benda uji \\
\cline { 2 - 2 } & Marshall konvensional \\
\hline 5.0 & 3 sampel \\
\hline 5.5 & 3 sampel \\
\hline 6.0 & 3 sampel \\
\hline 6.5 & 3 sampel \\
\hline 7.0 & 3 sampel \\
\hline Total & 15 sampel \\
\hline
\end{tabular}

\section{ANALISA DAN PEMBAHASAN}

\section{Analisis Karakteristik Filler Abu Jerami}

Berdasarkan hasil pemeriksaan yang telah dilakukan pada karakteristik filler abu jerami maka diperoleh berat jenis filler abu jerami sebesar 0,486. Pengujian ini berdasarkan Spesifikasi Bina Marga tahun 2018 dimana Spesifikasi Bina Marga 2018 tidak memberikan nilai batasan untuk berat jenis filler.

\section{Komposisi Campuran}

Setelah proporsi bahan telah diperoleh baik agregat, filler abu jerami, maupun kadar aspal maka dapat diketahui komposisi total pada campuran. Komposisi campuran yang digunakan adalah sebagai berikut.

\section{Tabel 2. Komposisi Total Campuran}

\begin{tabular}{cccccc}
\hline \multirow{2}{*}{ Kadar aspal \% } & \multicolumn{5}{c}{ Laston lapis aus } \\
\cline { 2 - 6 } & 5.0 & 5.5 & 6.0 & 6.5 & 7.0 \\
\hline Berat agregat & 1068 & 1062.6 & 1057.2 & 1051.8 & 1046.4 \\
\hline Berat filler abu jerami & 72 & 71.4 & 70.8 & 70.2 & 69.6 \\
\hline Berat aspal & 60 & 66 & 72 & 78 & 84 \\
\hline Berat campuran & 1200 & 1200 & 1200 & 1200 & 1200 \\
\hline
\end{tabular}

\section{Hasil perhitungan Bulk Specific Gravity dan Effective Spesific Gravity}

Benda uji dibuat dengan kadar aspal untuk LASTON lapis aus yaitu 5.0\%, 5.5\%, 6.0\%, 6.5\%, dan 7.0\%. Hasil perhitungan bulk specific gravity dan effective specific gravity adalah sebagai berikut.

Tabel 3. Bulk Specific Gravity Dan Effective Specific Gravity

\begin{tabular}{cccccc}
\hline \multirow{2}{*}{ Kadar aspal \% } & \multicolumn{5}{c}{ LASTON LAPIS AUS } \\
\cline { 2 - 6 } & 5,50 & 6,00 & 6,50 & 7,00 & 7,50 \\
\hline $\begin{array}{c}\text { Bulk Specific Gravity } \\
\text { Agregat }\end{array}$ & 2,17 & 2,18 & 2,20 & 2,21 & 2,22 \\
\hline $\begin{array}{c}\text { Effective Specific } \\
\text { Gravity Agregat }\end{array}$ & 2,20 & 2,21 & 2,23 & 2,24 & 2,25 \\
\hline
\end{tabular}




\section{Hasil Pengujian Marshall Campuran Laston Lapis Aus}

Berdasarkan hasil pengujian marshall karakteristik LASTON lapis aus maka diperoleh data sebagai berikut.

Tabel 4. Hasil Pengujian Karakteristik Campuran

\begin{tabular}{cccccc}
\hline Persyaratan & Min 800 (kg) & $3-5(\%)$ & $2-4(\mathrm{~m})$ & Min 14(\%) & Min 65 (\%) \\
\hline $\begin{array}{c}\text { Kadar Aspal } \\
(\%)\end{array}$ & Stabilitas & VIM & Flow & VMA & VFB \\
\hline 5,0 & 2565,74 & 4,39 & 2,62 & 12,66 & 65,35 \\
\hline 5,5 & 3256,34 & 4,17 & 2,37 & 13,43 & 68,92 \\
\hline 6,0 & 3472,46 & 4,09 & 2,21 & 14,43 & 71,40 \\
\hline 6,5 & 3169,88 & 4,01 & 2,26 & 15,22 & 73,62 \\
\hline 7,0 & 2982,57 & 3,92 & 2,65 & 16,11 & 75,62 \\
\hline
\end{tabular}

Hasil analisis stabilitas atau kemampuan lapisan permukaan dalam menerima beban tanpa perubahan bentuk dan pengikatan aspal semakin baik hal ini juga terlihat dengan turunnya nilai rongga dalam campuran (VIM). Walupun ronnga diantara partikel (VMA) dengan kadar aspal 5\% dan 5.5\% tidak memenuhi persyaratan Spesifikasi Bina Marga yang digunakan, namun dengan kadar aspal 6\%, 6.5\% dan 7\% masih memenuhi persyaratan. Dari Tabel 4 juga dapat diketahui nilai pelelehan menurun dengan kadar aspal 5\% sampai dengan 6\% namun dengan kadar 6.5\% sampai dengan 7\% nilai pelelehan (flow) cenderung memperlihatkan pertambahan. Nilai pelelhan ini masih pada batas persyaratan. Rongga yang terdapat diantara partikel agregat yang terisi oleh aspal (VFA) memperlihatkan kecenderungan meningkat.

\section{Penentuan Kadar Aspal Optimum (KAO)}

Berdasarkan hasil analisa beberapa parameter karakteristik marshall campuran LASTON lapis aus maka dapat ditentukan kadar aspal optimum dalam campuran tersebut. Seperti yang dijelaskan sebelumnya bahwa kadar aspal optimum pada LASTON lapis aus dipilih kadar aspal yang memilik nilai VIM terendah dan memenuhi semua kriteria karakteristik, hal ini dimaksudkan karena LASTON lapis aus merupakan bagian dari lapisan permukaan yang merupakan lapisan paling atas dan berfungsi sebagai lapisan pelindung dan kedap air. Maka dari itu kadar aspal yang dipilih yaitu kadar aspal 7,0\%.

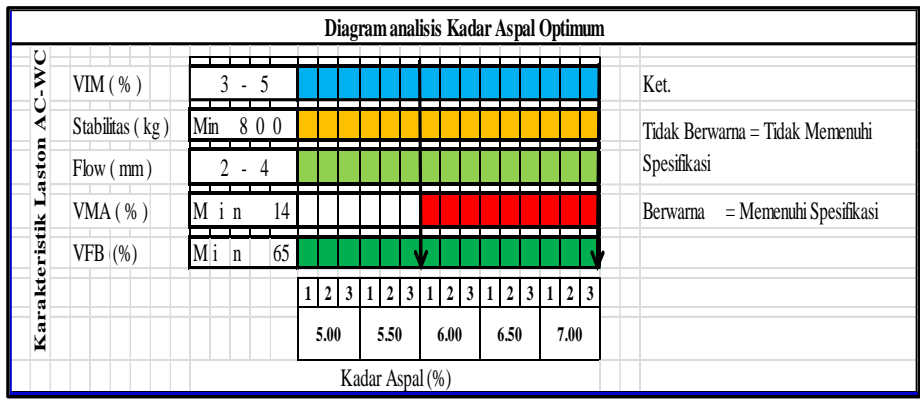

Gambar 4. Diagram kadar aspal optimum.

\section{KESIMPULAN}

Karakteristik campuran LASTON lapis aus yang menggunakan batu sungai Tiakka dan abu jerami sebagai bahan pengganti filler bila dibandingkan dengan Spesifikasi Bina Marga 2018 maka parameter karakteristik yaitu stabilitas, flow, VIM, dan VFB memenuhi spesifikasi dan pada VMA yang menggunakan kadar aspal 
5,0\%-5,5\% tidak memenuhi spesifikasi sedangkan VMA yang menggunakan kadar aspal 6,0\%-7,0\% memenuhi spesifikasi.

Berdasarkan hasil pengujian karakteristik campuran beraspal LASTON lapis aus yang menggunakan abu jerami sebagai pengganti filler melalui pengujian marshall konvensional maka dapat ditentukan kadar aspal optimum yaitu pada kadar aspal 7,0\%.

\section{DAFTAR PUSTAKA}

[1] G. Rusbintardjo, Aspal- Bahan Perkerasan Jalan, 1 ed. Semarang: UNISSULA Press, 2013.

[2] S. Sukirman, Beton Aspal Campuran Panas, Edisi Kedua. Jakarta: Yayasan Obor Indonesia, 2013.

[3] R. Rachman, "The Effect of Immersion and Humidification Toward Performance of Hot Rolled Asphalt Mixture," Int. J. Appl. Eng. Res., vol. 15, no. 5, hlm. 503-509, 2020.

[4] R. Krebs D. dan R. Walker D., Highway Materials,. Michigan: McGraw-Hill, Universitas Michigan, 1971.

[5] L. D. R. K. Salle, "Pemanfaatan Limbah,” dalam Pemanfaatan Material Alternatif (Sebagai Bahan Penyusun Konstruksi), Makassar: CV. Tohar Media, 2021, hlm. 59-68.

[6] A. R. Seppo, R. Rachman, dan N. Ali, "Variasi Suhu Pemadatan Campuran AC-WC Menggunakan Batu Sungai Balusu Kabupaten Toraja Utara," J. Matriks Tek. Sipil, vol. 9, no. 1, hlm. 23-31, 2021, doi: https://doi.org/10.20961/mateksi.v9i1.49248.

[7] A. Kusuma, "Material Subtitusi Filler," dalam Pemanfaatan Material Alternatif (Sebagai Bahan Penyusun Konstruksi), Makassar: CV. Tohar Media, 2021, hlm. 121-130.

[8] Direkorat Jenderal Bina Marga, Spesifikasi Umum Bina Marga 2018 untuk Pekerjaan Konstruksi Jalan dan Jembatan Divisi 6. Jakarta: Kementerian Pekerjaan Umum dan Perumahan Rakyat, 2018.

[9] C. Kamba, "Agregat dari Material Lokal," dalam Pemanfaatan Material Alternatif (Sebagai Bahan Penyusun Konstruksi), Makassar: CV. Tohar Media, 2021, hlm. 35-46.

[10] R. Rachman, "Pemanfaatan Batu Gunung Bottomale Toraja Utara sebagai Campuran Laston," J. Tek. Sipil Dan Teknol., vol. 6, no. 1, hlm. 20-30, 2020.

[11] R. Rachman, "Karakteristik Campuran HRS - BASE Menggunakan Bubuk Dolomit Sebagai Filler," dalam Konfrensi Nasional Teknik Sipil Ke 13, Banda Aceh, Sep 2019, vol. 1, hlm. 420-430.

[12] Alpius, "Campuran HRS-WC Menggunakan Agregat Batu Gunung Desa Palipu Kecamatan Mengkendek Tana Toraja," dalam Konferensi Nasional Teknik Sipil (KoNTekS) - 13, Banda Aceh, 2019, vol. 1, hlm. 431-441.

[13] G. P. Palimbunga, R. Rachman, dan Alpius, "Penggunaan Agregat Sungai Batu Tiakka' dalam Campuran ACBC," Paulus Civ. Eng. J., vol. 2, no. 2, hlm. 112-118, 2020.

[14] A. I. E. Pakka, R. Rachman, dan Alpus, "Karakteristik Campuran Laston Lapis Antara Menggunakan Abu Jerami Sebagai Bahan Substitusi Filler," Paulus Civ. Eng. J., vol. 3, no. 3, hlm. 441-447, 2021.

[15] P. E. D. Malacca, "Pemanfaatan Limbah Abu Sekam Padi (Rice Husk Ash) Sebagai Subtitusi Material Pengisi Campuran AC-WC Terhadap Karakteristik Marshall,” Skripsi, Program Studi Teknik Sipil Fakultas Teknik Universitas Muhammadiyah Mataram, Mataram, 2021.

[16] R. Afifi, A. Malik, dan G. Wibisono, "Pengaruh Penggantian Bahan Pengisi Semen Dengan Kombinasi Abu Bata Dan Abu Sekam Padi Pada Campuran Aspal AC-WC,”Jom FTEKNIK, vol. 5, no. 2, 2018.

[17] F. S. Ridwan dan Nadia, "Analisis Pengaruh Pemanfaatan Abu Sekam Sebagai Filler Pada Campuran Aspal Beton,” J. Konstr., vol. 8, no. 2, hlm. 1-8, 2018. 